\title{
From Liquid to Solid-State Fluorescence: Tricyclic Lactones Based on 4-Hydroxy-1,3-thiazoles
}

\author{
Lorena K. Calderón Ortiz, ${ }^{a}$ Hendryk Würfel, ${ }^{\mathrm{a}}$ Eric Täuscher, ${ }^{\mathrm{b}}$ Dieter Weiß, ${ }^{* a}$ Eckhard Birckner, ${ }^{\mathrm{c}}$ Helmar Görls, ${ }^{\mathrm{d}}$ \\ Rainer Beckert*a \\ ${ }^{a}$ Institute of Organic and Macromolecular Chemistry, Friedrich-Schiller-University Jena, Humboldtstr. 10, 07743 Jena, Germany \\ Fax+49(3641)948212; E-mail: C6bera@uni-jena.de \\ b Department of Chemistry and Biotechnology, Technical University of Ilmenau, Weimarer Str. 25, 98693 Ilmenau, Germany \\ c Institute of Physical Chemistry, Friedrich-Schiller-University Jena, Lessingstr. 10, 07743 Jena, Germany \\ d Institute of Inorganic and Analytical Chemistry, Friedrich-Schiller-University Jena, Humboldtstr. 9, 07743 Jena, Germany \\ Received: 14.08.2013; Accepted after revision: 30.09.2013 \\ Dedicated to Prof. Dr. W. Kantlehner, Aalen on the occasion of his 70th birthday
}

\begin{abstract}
This work describes the synthesis of a series of tricyclic lactones based on 4-hydroxy-1,3-thiazoles prepared by the classic Hantzsch synthesis. The tricyclic lactones are more rigid than the parent 4-hydroxythiazoles and are featured not only by fluorescence in solution, but also in the solid state. An extension of the chromophoric system was successfully realized by integration of the benzothiazole substructure, thus resulting in bathochromic shifts of absorption and also fluorescence. The new synthesized lactones additionally show interesting properties in solution, whereby the initial blue fluorescence changes dramatically with a variation of the $\mathrm{pH}$ value.
\end{abstract}

Key words: heterocycles, chromophores, fused-ring systems, thiazole, fluorescence

4-Hydroxy-1,3-thiazoles and their derivatives have been intensively studied in the last few years, because they represent a new class of functional fluorophores. ${ }^{1,2}$ In addition, they form the substructure of several natural products and were chosen by nature as part of the chemical compound responsible for the dual luminescence of the firefly (lampyridae). ${ }^{3}$ The remarkable spectroscopic properties of this heterocycle as fluorophore and chromophore, and its easy feasibility of functionalization enable the development of a variety of novel applications. They have been used as novel ligands for metal complexes, emitting polymers, dyes, and sensors. ${ }^{4-8}$ Furthermore, it is known that the extension of the $\pi$-system attached to the thiazole ring by substitution with aromatic heterocycles allows the modification of its photophysical properties. ${ }^{3,7}$

Consequently, we were interested in the synthesis of a new class of thiazole-based derivatives containing a ringfused $\pi$-system. The reaction of dimethyl $\alpha$-bromohomophthalate with various thioamides should be suitable in order to obtain annulated thiazoles by intramolecular esterification. In contrast to most of the fluorescent dyes described in literature, ${ }^{9}$ these novel thiazole derivatives are highly fluorescent in solution as well as in the solid state. Solid-state fluorescence attracts a lot of attention because

SYNTHESIS 2014, 46, 0126-0134

Advanced online publication: 04.11.2013

DOI: 10.1055/s-0033-1340048; Art ID: SS-2013-T0566-OP

(C) Georg Thieme Verlag Stuttgart · New York of its applicability as an emitter material in organic electroluminescence devices (OLEDs), solid-state dye lasers and sensor materials, and the potential use in the construction of optoelectronic devices. ${ }^{9,10}$ It is well known that the photophysical properties of these compounds depend strongly on the nature of their conjugated $\pi$-system, their geometry in the solid state, and their packing in the crystal. ${ }^{10 \mathrm{c}, \mathrm{d}}$

The tricyclic lactones based on 4-hydroxy-1,3-thiazoles were synthesized according to the classic Hantzsch synthesis $^{3}$ in moderate up to good yields $(79 \%)$. As depicted in Scheme 1, different thioamides 2 react with dimethyl $\alpha$-bromohomophthalate (1) in DMF in the presence of triethylamine at $120^{\circ} \mathrm{C}$ to furnish the tricyclic lactones 4 . In order to get more information about the influence of an extended $\pi$-system, the benzo $[d]$ thiazole-2carbothioamides $\mathbf{3}$ were used to obtain the lactones $\mathbf{5}$.

The new tricyclic lactones $4 \mathbf{a}-\mathbf{c}$ were isolated as colorless to beige-colored needles, whereas compound $\mathbf{4 d}$ and all derivatives of type $\mathbf{5}$ were isolated as yellow crystalline solids. They have high melting points (from 200 up to $340^{\circ} \mathrm{C}$ ) and can be purified by recrystallization from DMSO or DMF. The compounds show a high solubility in a mixture of $\mathrm{CHCl}_{3}-\mathrm{CF}_{3} \mathrm{CO}_{2} \mathrm{H}$ or $o$-dichlorobenzene, while they are only slightly soluble in polar organic solvents, such as DMSO, DMF, and $\mathrm{EtOH}$.

All of these new thiazole derivatives were fully characterized by NMR, MS, and elemental analysis. In addition, suitable single crystals of $\mathbf{4 d}$ and $5 \mathbf{a}$ were obtained for Xray analysis. The ORTEP plots of the structures are shown in Figure 1. Compound 4d shows a bond length of 1.443 (3) $\AA$ for C4-C5 connecting the thiophene ring with the tricyclic lactone, whereas compound 5a shows a bond length of 1.453 (3) $\AA$ for C7-C8 between the benzothiazole moiety and the tricyclic lactone. Both compounds show an almost coplanar structure, due to their torsion angles between the heterocyclic moieties of $176.20(2)^{\circ}$ around the S1-C4-C5-S2 planes for $\mathbf{4 d}$ and $174.42(1)^{\circ}$ around the S1-C7-C8-S2 planes for $\mathbf{5 a}$. 

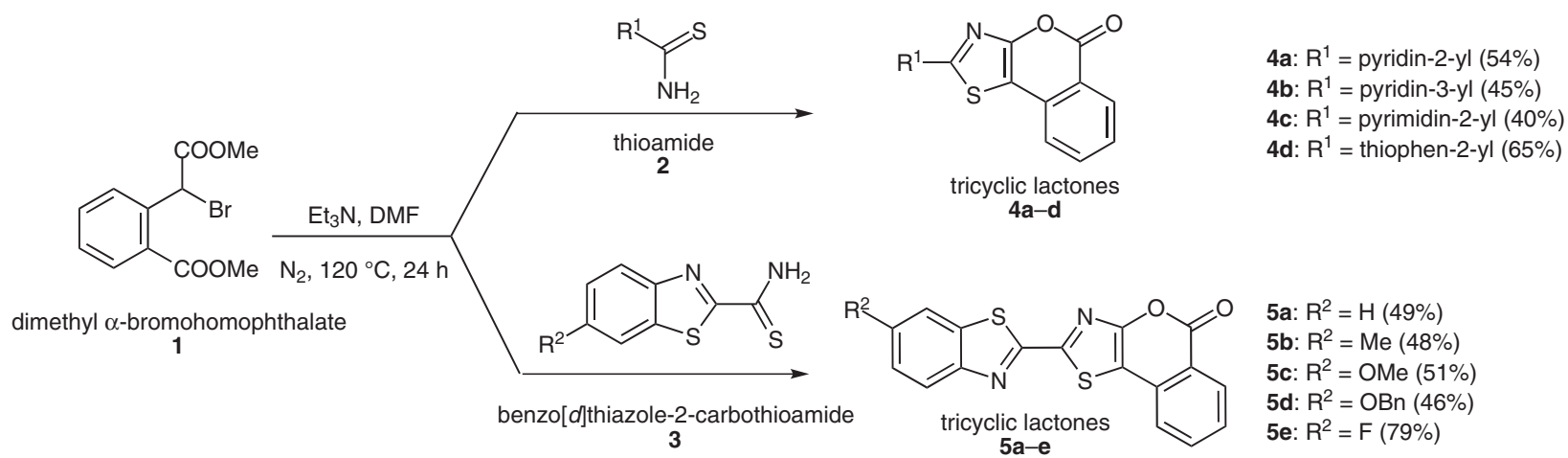

Scheme 1 Synthesis of tricyclic lactones based on 4-hydroxy-1,3-thiazoles

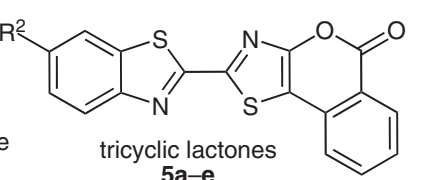

$\mathrm{H}(49 \%)$ 5b: $R^{2}=\operatorname{Me}(48 \%)$ 5c: $R^{2}=$ OMe $(51 \%)$

5d: $R^{2}=$ OBn $(46 \%)$ 5e: $R^{2}=F(79 \%)$

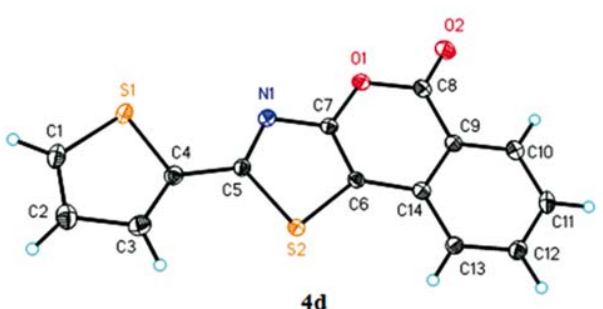

$4 d$

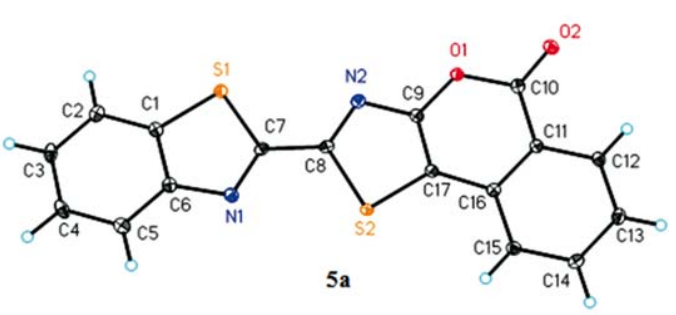

Figure 1 ORTEP plot of the solid-state molecular structure (X-ray crystallographic analysis) of tricyclic lactones $\mathbf{4 d}$ and $\mathbf{5 a}$

The most important feature of tricyclic lactone derivatives, however, is their solid-state fluorescence. With regard to subsequent applications, this type of luminescence was investigated for derivatives in the series 4 and $\mathbf{5}$. Under UV radiation, the tricyclic lactones $\mathbf{4 a}-\mathbf{c}$ are highly fluorescent in the violet-blue region (450-480 nm), whereas $\mathbf{4 d}$ and the compounds $\mathbf{5 a}-\mathbf{e}$ fluoresce in the green-yellow region of the spectrum (490-580 nm). Figure 2 shows the solid-state fluorescence of the tricyclic lactones under UV radiation and their spectral profiles are depicted in Figure 3.

Comparing compounds $\mathbf{4}$, the presence of a pyridin-2-yl $\left(R^{1}\right)$ substituent in $\mathbf{4 a}$ does not only result in a hypsochromic shift of the solid-state fluorescence, but also in a significant increase of the solid-state quantum yield $\left(\lambda_{\mathrm{Fl}}=456 \mathrm{~nm} ; \Phi_{F l}=0.32\right)$. The introduction of a substituent at $\mathrm{R}^{2}$ in the series of compounds 5 results in a decrease of the quantum yield, where donors have a lower influence than acceptor groups. Therefore, the introduction of fluorine strongly reduces the fluorescence intensity $\left(\Phi_{F l}\right.$ : $\left.\mathbf{5 a}=0.40: \mathrm{R}^{2}=\mathrm{H} ; \Phi_{F l}: \mathbf{5 e}=0.07: \mathrm{R}^{2}=\mathrm{F}\right)$.<smiles>[R]c1nc2oc(=O)c3ccccc3c2s1</smiles>

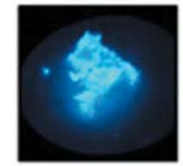

$\mathrm{R}^{1}$ :

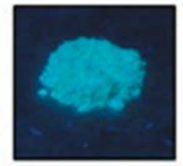

pyridin-3-yl

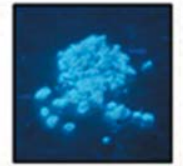

pyrimidin-2-yl thiophen-2-yl

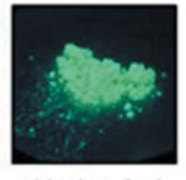<smiles>[R]c1ccc2nc(-c3nc4oc(=O)c5ccccc5c4s3)sc2c1</smiles>

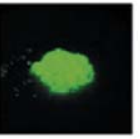

$\mathrm{H}$

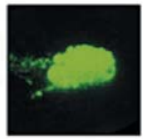

$\mathrm{Me}$

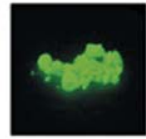

$\mathrm{OMe}$

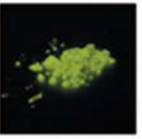

$\mathrm{OBn}$

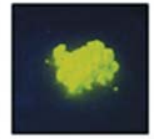

F
Figure 2 Solid-state fluorescence of $\mathbf{4}$ and $\mathbf{5}$ under UV irradiation

The tricyclic lactones $\mathbf{4}$ and $\mathbf{5}$ show absorption maxima in the UVA region (315 to $400 \mathrm{~nm}$ ) in solution and are highly fluorescent in the violet-blue region of the visible spectrum. However, the fluorescence maxima of these compounds are considerably hypsochromically shifted compared to their solid-state fluorescence maxima.

The influence of the solvent is reflected in the absorption and fluorescence data (Table1). The absorption and fluorescence bands of $\mathbf{4 a}, \mathbf{4 b}$, and $\mathbf{4 c}$ in $\mathrm{EtOH}$, having pyridine or pyrimidine moieties at $\mathrm{R}^{1}$, are very similar, whereas the absorption/fluorescence bands of compound 4d with a thiophene ring are significantly red-shifted. The modification of $\mathrm{R}^{2}$ in derivatives 5 influences also the photophysical properties. The shifts between compounds $\mathbf{5 a}, \mathbf{5 b}$, and 5e compared to derivatives $\mathbf{5 c}$ and $\mathbf{5 d}$ are about $\lambda_{\mathrm{Abs}}=10$ $\mathrm{nm}$ and $\lambda_{\mathrm{Fl}}=20 \mathrm{~nm}$, hypsochromically. The latter molecules depict the highest Stokes shifts in this group of compounds [5c and 5d: $\Delta \tilde{\mathbf{v}}(\mathrm{EtOH})=3900 \mathrm{~cm}^{-1}$ ]. 

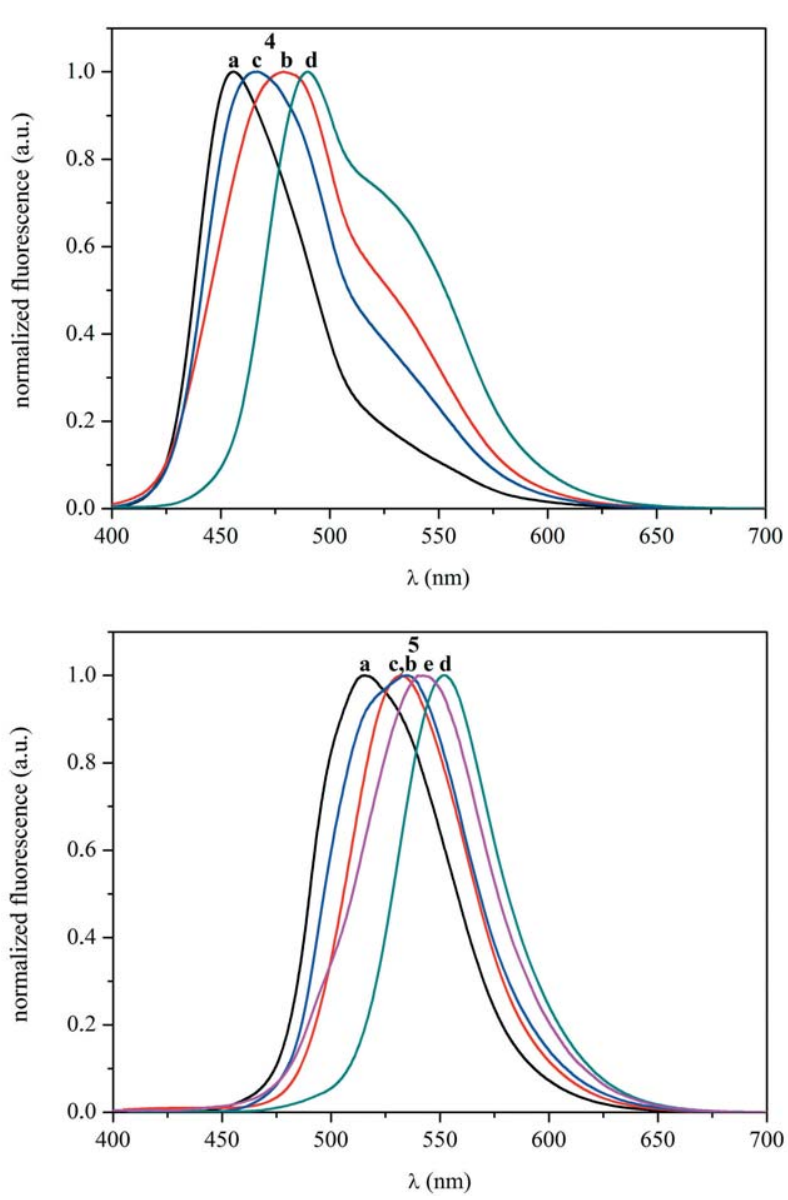

Figure 3 Solid-state fluorescence spectra of compounds $4\left(\lambda_{\mathrm{Ex}}=420\right.$ $\mathrm{nm})$ and $\mathbf{5}\left(\lambda_{\mathrm{Ex}}=450 \mathrm{~nm}\right)$.
When the solvent is changed from EtOH to DMSO, the spectra of all compounds are red-shifted and in most cases show a slight increase of the Stokes shift, for example, for 5a: $(\mathrm{EtOH}-\mathrm{DMSO}): \lambda_{\mathrm{Abs}}=388 / 395 \mathrm{~nm} ; \lambda_{\mathrm{Fl}}=450 / 463 \mathrm{~nm}$, and $\Delta \widetilde{v}=3550 / 3720 \mathrm{~cm}^{-1}$.

The fluorescence quantum yields of the tricyclic lactones in DMSO reflect the structural variation of each derivative measured. Compound 4a containing the pyridin-2-yl moiety $\left(\mathrm{R}^{1}\right)$ has the highest quantum yield within this first group of compounds $\Phi_{F l}(\mathrm{DMSO})=0.59$, which is common for this kind of substituent, as described in the literature. ${ }^{1,8}$

In the second group, compounds $\mathbf{5 c}, \mathbf{5 d}$, and $\mathbf{5 e}$ with either a strong donor or acceptor group $\mathrm{R}^{2}$ show the highest quantum yields: $\Phi_{F l}(\mathrm{DMSO})=0.83,0.61$, and 0.61 , respectively.

The integration of the benzothiazole substructure in the $\pi$ system of the tricyclic lactones $\mathbf{5}$ has a significant influence on the quantum yield of the compounds in both solid state and solution. In general, compounds of type $\mathbf{5}$ absorb bathochromically and their fluorescence is stronger than those of type 4. Table 1 shows the UV-Vis and fluorescence data of the tricyclic lactones $\mathbf{4}$ and $\mathbf{5}$ in solution and solid state.

In addition, the chemical behavior of tricyclic lactones in basic and acidic media was also investigated. All spectroscopic data are shown in Table 2 and the resulting species in Scheme 2.

Treating solutions of compounds $\mathbf{4}$ or $\mathbf{5}$ with inorganic $(\mathrm{NaOH}, \mathrm{KOH})$ or organic bases (tetrabutylammonium hydroxide) results in a color change to a deep red and, simul-

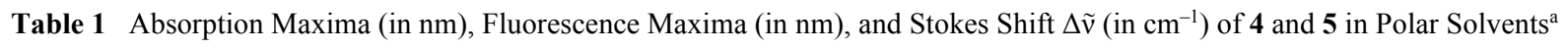

\begin{tabular}{|c|c|c|c|c|c|c|c|c|c|}
\hline \multirow[b]{2}{*}{ Entry } & \multicolumn{3}{|c|}{ In EtOH } & \multicolumn{4}{|c|}{ In DMSO } & \multicolumn{2}{|c|}{ Solid state } \\
\hline & $\lambda_{\mathrm{Abs}}$ & $\lambda_{\mathrm{Fl}}$ & $\Delta \widetilde{v}$ & $\lambda_{\mathrm{Abs}}$ & $\lambda_{\mathrm{Fl}}$ & $\Delta \tilde{v}$ & $\Phi_{\mathrm{Fl}} \pm 0.10^{\mathrm{b}}$ & $\lambda_{\mathrm{Fl}}$ & $\Phi_{\mathrm{Fl}} \pm 0.20^{\mathrm{c}}$ \\
\hline $4 a$ & 362 & 420 & 3820 & 368 & 428 & 3810 & 0.59 & 456 & 0.32 \\
\hline $4 b$ & 360 & 420 & 3970 & 362 & 428 & 4260 & 0.39 & 479 & 0.05 \\
\hline $4 c$ & 360 & 424 & 4190 & 364 & 432 & 4320 & 0.23 & 467 & 0.12 \\
\hline $4 d$ & 376 & 446 & 4170 & 382 & 451 & 4010 & 0.47 & 490 & 0.07 \\
\hline $5 a$ & 388 & 450 & 3550 & 395 & 463 & 3720 & 0.54 & 518 & 0.40 \\
\hline $5 b$ & 392 & 454 & 3480 & 399 & 467 & 3650 & 0.55 & 532 & 0.31 \\
\hline $5 c$ & 400 & 474 & 3900 & 407 & 478 & 3650 & 0.83 & 535 & 0.27 \\
\hline $5 d$ & 400 & 474 & 3900 & 408 & 479 & 3630 & 0.61 & 552 & 0.13 \\
\hline $5 e$ & 388 & 450 & 3550 & 395 & 461 & 3620 & 0.61 & 542 & 0.07 \\
\hline
\end{tabular}

${ }^{a}$ Quantum yield in DMSO and in solid state.

${ }^{\mathrm{b}}$ Determined using quinine sulfate in $0.1 \mathrm{~N}$ aq $\mathrm{H}_{2} \mathrm{SO}_{4}$ as standard.

${ }^{\mathrm{c}}$ Determined with an integrating sphere $4\left(\lambda_{\mathrm{Ex}}=420 \mathrm{~nm}\right)$ and $\mathbf{5}\left(\lambda_{\mathrm{Ex}}=450 \mathrm{~nm}\right)$. 


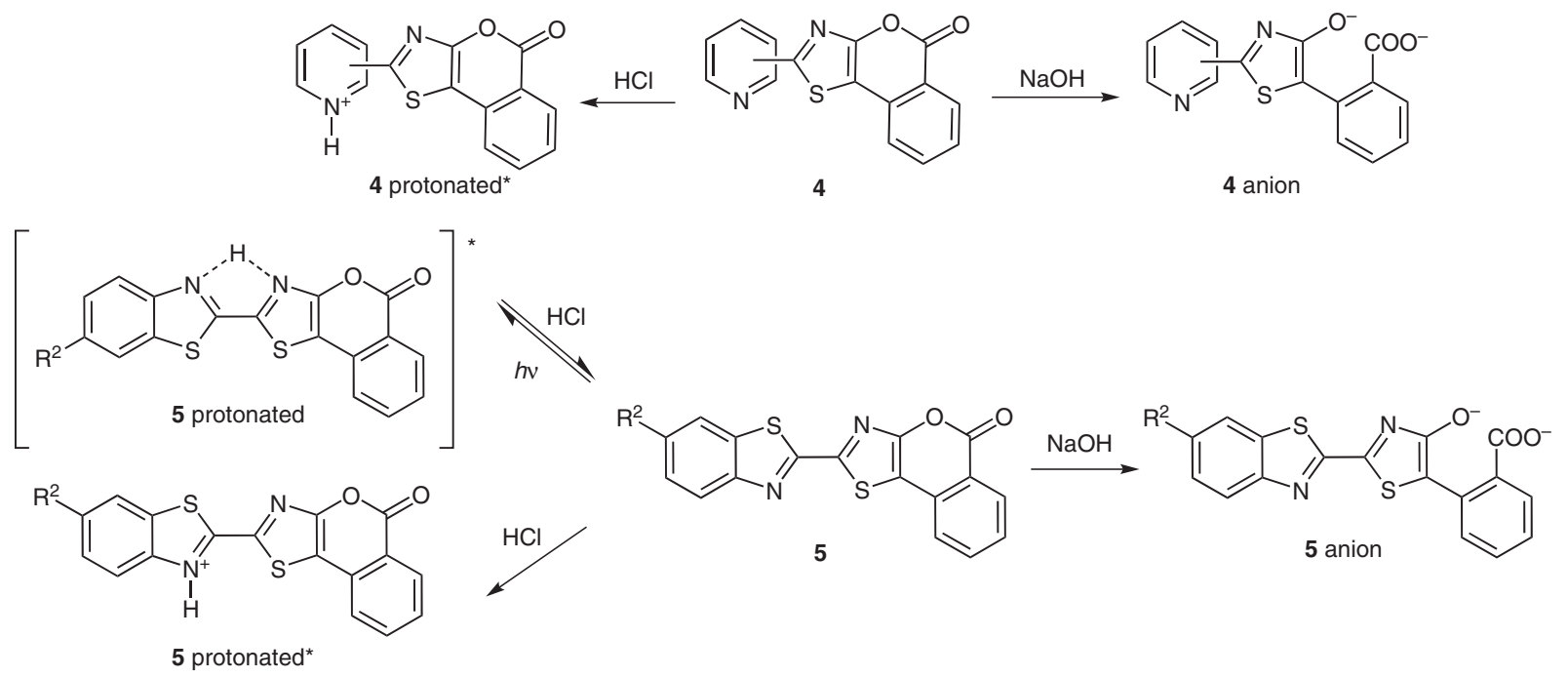

Scheme 2 Treatment of derivatives $\mathbf{4}$ and $\mathbf{5}$ with bases or acids

Table 2 Absorption Maxima (in nm), Fluorescence Maxima (in nm), and Stokes Shift $\Delta \tilde{v}$ (in $\mathrm{cm}^{-1}$ ) of $\mathbf{4}$ and $\mathbf{5}$ after Addition of $\mathrm{NaOH}$ and $\mathrm{HCl}$ in Polar Solvents

\begin{tabular}{|c|c|c|c|c|c|c|c|c|c|}
\hline \multirow[b]{3}{*}{ Entry } & \multirow{2}{*}{\multicolumn{3}{|c|}{$\begin{array}{l}\text { In DMSO } \\
+\mathrm{NaOH}\end{array}$}} & \multicolumn{6}{|c|}{ In EtOH } \\
\hline & & & & \multicolumn{3}{|c|}{$+\mathrm{NaOH}$} & \multicolumn{3}{|c|}{$+\mathrm{HCl}$} \\
\hline & $\lambda_{\mathrm{Abs}}$ & $\lambda_{\mathrm{F} 1}$ & $\Delta \tilde{v}$ & $\lambda_{\mathrm{Abs}}$ & $\lambda_{\mathrm{F} 1}$ & $\Delta \tilde{v}$ & $\lambda_{\mathrm{Abs}}$ & $\lambda_{\mathrm{Fl}}$ & $\Delta \tilde{v}$ \\
\hline $4 a$ & 496 & 620 & 4030 & 442 & 598 & 5900 & 364 & 476 & 6460 \\
\hline $4 b$ & 476 & 614 & 4720 & 434 & 592 & 6150 & 366 & 478 & 6400 \\
\hline $4 c$ & 510 & 626 & 3630 & 452 & 598 & 5400 & 360 & 480 & 6940 \\
\hline $4 d$ & 490 & 622 & 4330 & 434 & 592 & 6150 & 378 & 448 & 4130 \\
\hline $5 a$ & 536 & 644 & 3130 & 472 & 620 & 5060 & 388 & 492 & 5450 \\
\hline $5 b$ & 530 & 640 & 3240 & 470 & 618 & 5100 & 394 & 496 & 5220 \\
\hline $5 c$ & 530 & 636 & 3150 & 466 & 616 & 5230 & 402 & 504 & 5030 \\
\hline $5 d$ & 530 & 636 & 3150 & 474 & 618 & 4920 & 402 & 508 & 5190 \\
\hline $5 e$ & 542 & 644 & 2920 & 474 & 622 & 5020 & 388 & 474 & 4680 \\
\hline
\end{tabular}

taneously, to an orange-red fluorescence. This effect could be observed visually in $\mathrm{MeCN}$, EtOH, $\mathrm{MeOH}$, THF, and especially in DMSO, where the red color is much stronger. This color change is characteristic for 4-hydroxy-1,3-thiazoles in the presence of bases and can be attributed to the formation of the thiazol-4-olate anion. . $^{2,7,8}$ Therefore, it is obvious that the compounds reported here undergo a ring-opening reaction of the lactone, which is common for coumarins under basic conditions. ${ }^{11}$ This ring-opening of the lactone ring is an irreversible process in water and can already be observed at room temperature at pH 9.97 (see Figure S1, Supporting Information).

In an additional experiment performed by the addition of $\mathrm{NaOH}(0.01 \mathrm{~N})$ to a solution of $\mathbf{4}$ and $\mathbf{5}$ in EtOH and in DMSO, the determination of the spectroscopic data of ring-opened compounds was possible (Table 2). The color change observed is strongly influenced by the nature of the solvent as well as of the substituent present in each compound.

In detail, upon the addition of a base to a solution of $4 \mathbf{a}$ in $\mathrm{EtOH}$, the emission shows a redshift of $178 \mathrm{~nm}$ : $\lambda_{\mathrm{Fl}}(\mathrm{EtOH}) \mathbf{4 a} / \mathbf{4} \mathbf{a}_{\text {anion }}=420 / 598 \mathrm{~nm}$, whereas in DMSO, this shift increases to $192 \mathrm{~nm}: \lambda_{\mathrm{Fl}}(\mathrm{DMSO}) \mathbf{4 a} / \mathbf{4} \mathbf{a}_{\text {anion }}=$ $428 / 620 \mathrm{~nm}$. In the case of compounds of type 5 , the benzothiazole moiety influences this effect in a way that all absorption and fluorescence maxima are shifted to the red region in both solvents compared with types 4 . In EtOH, however, the absorption and fluorescence bands of all anions formed are blue-shifted and, additionally, the Stokes shift is higher than in DMSO. 
The observations made under acidic conditions were only reproducible in EtOH and, in contrast, no changes in solvents such as DMSO, THF, or MeCN were detected. The addition of $\mathrm{HCl}$ to a solution of $\mathbf{4}$ or $\mathbf{5}$ in $\mathrm{EtOH}$ at room temperature resulted in a green fluorescence, which was measured immediately. After the addition of 2 and 3 equivalents of $\mathrm{HCl}(0.01 \mathrm{~N})$ to solutions of $\mathbf{4}$ and $\mathbf{5}$, respectively, the fluorescence spectra of compounds $\mathbf{4 a}, \mathbf{4 b}$, and $4 \mathbf{c}$ exhibited a bathochromic shift of emission of around $55 \mathrm{~nm}$ : $\lambda_{\mathrm{Fl}}(\mathrm{EtOH}) \mathbf{4 a} / \mathbf{4 a}+\mathrm{H}^{+}=420 / 476 \mathrm{~nm}$, whereas those of compounds $\mathbf{5}$ are bathochromically shifted only about $40 \mathrm{~nm}$ : $\lambda_{\mathrm{Fl}}(\mathrm{EtOH}) \mathbf{5 a} / \mathbf{5 a}+\mathrm{H}^{+}=$ $450 / 492 \mathrm{~nm}$.

This can be explained considering the basicity of the pyridine nitrogen $\left(\mathrm{pKa}_{\mathrm{aH}}=5.2\right)^{12}$ present in compounds $\mathbf{4 a}$, $\mathbf{4 b}$, and $\mathbf{4 c}$ and its ability to be protonated resulting in pyridinium ions, which strongly modifies the $\pi$-system. This hypothesis was confirmed by adding $\mathrm{HCl}$ to a solution of 4d containing a thiophene ring $\left(R^{1}\right)$, which does not result in such a considerable shift.

The reason for the smaller but also significant shift in the fluorescence spectra of compounds of type 5 might be, on the one hand, the protonation of the aza atoms of the two thiazole rings or, on the other hand, a change of geometry. The crystal structure of 5a (Figure 1) clearly shows a trans arrangement of the two heterocyclic nitrogens, while the $\mathrm{C}-\mathrm{C}$ bond has a partial double bond character $(\mathrm{C} 7-\mathrm{C} 8=1.453 \AA)$. Considering the excited state, the heterocyclic moieties are able to rotate around this bond, leading to a chelating 1,4-diazadiene substructure. The latter is now capable of efficiently trapping a proton, thus, leading to an energy minimized structure ${ }^{13}$ (Scheme 2).

Examples of all resulting species upon treatment of compound $\mathbf{4 a}$ with acid/base and their fluorescence spectra are shown in Figure 4.

In conclusion, the present work describes the synthesis of tricyclic lactones based on 4-hydroxy-1,3-thiazoles synthesized by the classic Hantzsch synthesis. This novel class of thiazole derivatives is featured by fluorescence in solid state as well as in solution. The solid-state fluorescence of these compounds and their spectroscopic properties in solution have been investigated in detail.

In the crystalline state, the tricyclic lactones of type $\mathbf{4}$ and 5 are almost coplanar, resulting in an extension of the chromophore. Compounds $\mathbf{4 a}, \mathbf{4 b}$, and $\mathbf{4 c}$ show solid-state fluorescence in the blue region of the visible spectrum, whereas the donor character of the thiophene ring in $\mathbf{4 d}$ leads to a slight shift to longer wavelengths. The extension of the $\pi$-system in compounds of type 5 resulted in green to yellow fluorescence in their solid state.

When a base is added in solution, a drastic change of absorption and of fluorescence is observed. The lactone ring-opening process leads to deprotonated 4-hydroxythiazoles, which, due to their electronically altered $\pi$-systems, display fluorescence in the orange to red region of the visible spectrum. Derivatives $\mathbf{4 a}, \mathbf{4 b}$, and $\mathbf{4 c}$, which form pyridinium ions and compounds $\mathbf{5}$, which contain an
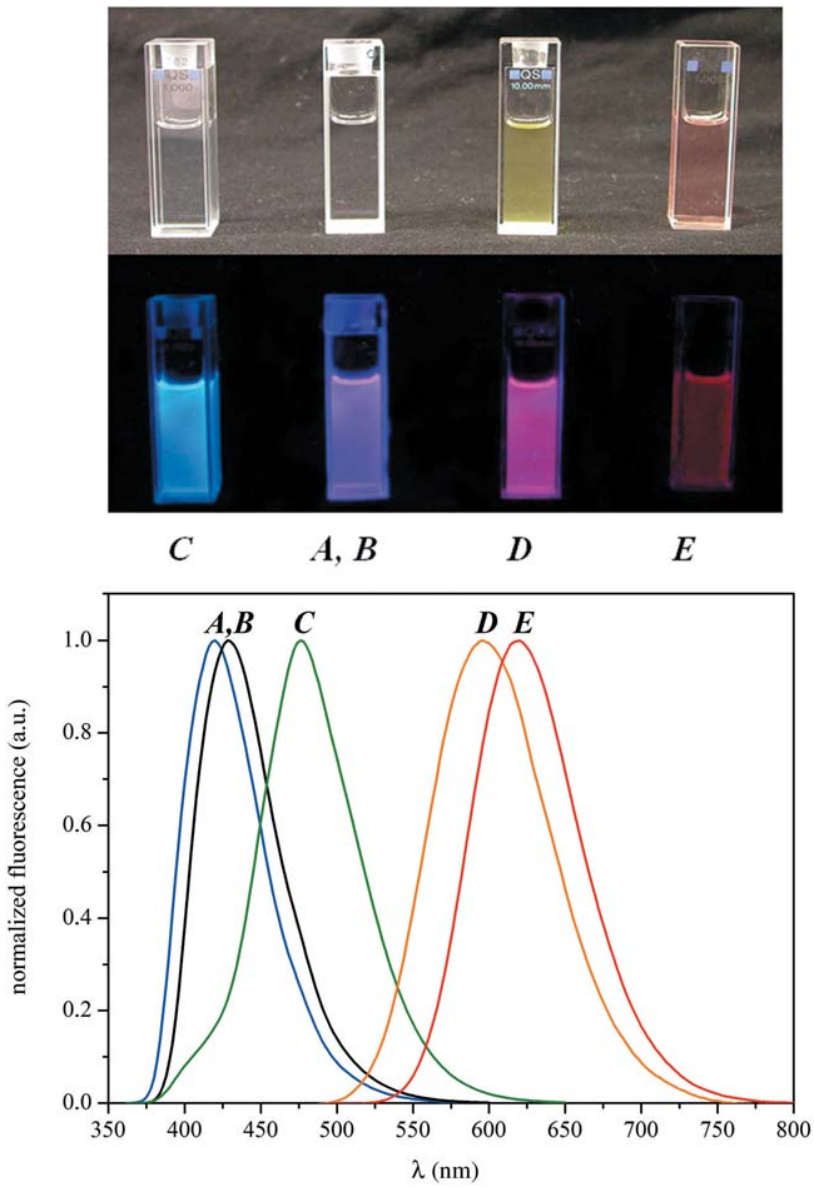

Figure 4 Color of the species formed from $\mathbf{4 a}$ after addition of $\mathrm{NaOH}$ and $\mathrm{HCl}$ under daylight and $\mathrm{UV}$ radiation and their normalized fluorescence spectra. $\mathbf{4 a}=2 \times 10^{-5} \mathrm{~mol} \mathrm{~L} \mathrm{~L}^{-1} ; \mathrm{NaOH}=0.01 \mathrm{~N}$, $\mathrm{HCl}=0.01$ N. $\boldsymbol{A}$ : in $\mathrm{EtOH} ; \boldsymbol{B}$ : in DMSO; $\boldsymbol{C}:+\mathrm{H}^{+}$in $\mathrm{EtOH} ; \boldsymbol{D}$ : $+\mathrm{NaOH}$ in EtOH; $\boldsymbol{E}:+\mathrm{NaOH}$ in DMSO.

additional aza-nitrogen in the neighboring pyridine ring, show a strong green fluorescence upon the addition of acids. A geometry change is discussed as a reason for this unusual shift.

Reagents were purchased from commercial sources and were used directly. The solvents were of reagent and spectroscopic grade. Reactions were monitored by TLC $(0.2 \mathrm{~mm}$ Merck silica gel plates 60 $\left.\mathrm{F}_{254}\right) .{ }^{1} \mathrm{H}$ and ${ }^{13} \mathrm{C}$ NMR spectra (in $\mathrm{CDCl}_{3}$ or DMSO- $d_{6}$ as solvent) were recorded on Bruker Avance 125 and 400 spectrometers. Mass spectrometry was carried out on a VG Trio-2000 quadrupole mass spectrometer and elemental analysis (CHNOS) was performed using a Vario EL III equipment. Melting points (uncorrected) were measured using a Büchi B-545 apparatus and IR spectra were recorded on a JASCO FT/IR 6300 spectrophotometer. UV/Vis and fluorescence spectra were recorded in solution on a Thermo/ UNICAM UV 500 spectrophotometer and on a JASCO FP-6500 spectrofluorimeter, respectively. Fluorescence spectra of the solidstate were recorded on a JASCO FP-8300 spectrophotometer. A PerkinElmer Lambda $750 \mathrm{UV} / \mathrm{Vis} / \mathrm{NIR}$ spectrophotometer was used to calculate the Quantum Yield of the compounds in solution and integrating sphere inserted in the fluorescence spectrometer CD900FS (Edinburgh Analytical Instruments) was used to calculate the absolute photoluminescence quantum yields of powder samples. 
Determination of Solid-State Fluorescence Quantum Yields: The absolute photoluminescence quantum yields of powder samples has been determined with an integrating sphere inserted in the fluorescence spectrometer CD900FS (Edinburgh Analytical Instruments). A custom designed sphere (Mod. 05-105, AMKO) with an inner diameter of $105 \mathrm{~mm}$, coated inside with $\mathrm{BaSO}_{4}$ was used. The excitation source was a tungsten lamp of variable intensity in order to get suitable conditions for the measurement of the fluorescence and scattered excitation light. The measured spectra of scattered excitation light without $\left(\mathrm{S}_{0}\right)$ and with $\left(\mathrm{S}_{\mathrm{S}}\right)$ sample and of the sample fluorescence $\left(\mathrm{S}_{\mathrm{S}}\right)$ were corrected regarding the spectral sensitivity of the detector and the spectral reflectance of the sphere and are to be integrated in the spectral region of the excitation and the fluorescence. The fluorescence quantum yield was calculated with $\Phi_{\mathrm{f}}=\mathrm{F}_{\mathrm{S}} /\left(\mathrm{S}_{0}-\mathrm{S}_{\mathrm{S}}\right)$ (see Figure $\mathrm{S} 2$, Supporting Information).

Crystal Structure Determination: The intensity data for the compounds were collected on Nonius Kappa CCD diffractometer using graphite-monochromated $\mathrm{MoK}_{\alpha}$ radiation. Data were corrected for Lorentz and polarization effects but not for absorption effects. ${ }^{14,15}$ The structures were solved by direct methods (SHELXS) and refined by full-matrix least squares techniques against $\mathrm{Fo}^{2}$ (SHELXL97). ${ }^{16}$ The hydrogen atoms of $5 \mathbf{a}$ were located by difference Fourier synthesis and refined isotropically. The hydrogen atoms of $\mathbf{4 d}$ were included at calculated positions with fixed thermal parameters. All nondisordered, non-hydrogen atoms were refined anisotropically. ${ }^{16}$ XP system (Siemens Analytical X-ray Instruments, Inc.) was used for structure representations.

\section{Dimethyl $\alpha$-Bromohomophthalate (1)}

A mixture of dimethyl homophthalate $(33 \mathrm{mmol}, 7.0 \mathrm{~g}$ ) prepared as described previously ${ }^{17}$ and NBS (57 mmol, $10.2 \mathrm{~g}$ ) in anhydrous $\mathrm{CH}_{2} \mathrm{Cl}_{2}(170 \mathrm{~mL})$ was stirred under reflux by irradiating with an UV-light lamp. After $18 \mathrm{~h}$, the solution was filtered off and the filtrate was sequentially washed with aq $10 \% \mathrm{NaHCO}_{3}(50 \mathrm{~mL})$, aq $10 \% \mathrm{NaHSO}_{3}(50 \mathrm{~mL})$, and brine $(50 \mathrm{~mL})$. The solvent was evaporated and the product was purified by column chromatography (EtOAc- $n$-heptane, 1:2); yield: $6.6 \mathrm{~g}$ (23.1 mmol, 70\%); light yellow oil.

${ }^{1} \mathrm{H}$ NMR $\left(250 \mathrm{MHz}, \mathrm{CDCl}_{3}\right): \delta=7.96(\mathrm{dd}, J=7.8,1.2 \mathrm{~Hz}, 1 \mathrm{H})$, $7.87(\mathrm{~d}, J=8.2 \mathrm{~Hz}, 1 \mathrm{H}), 7.61-7.5(\mathrm{~m}, 1 \mathrm{H}), 7.43-7.37(\mathrm{~m}, 1 \mathrm{H})$, $6.58(\mathrm{~s}, 1 \mathrm{H}), 3.91(\mathrm{~s}, 3 \mathrm{H}), 3.78(\mathrm{~s}, 3 \mathrm{H})$.

${ }^{13} \mathrm{C} \mathrm{NMR}\left(63 \mathrm{MHz}, \mathrm{CDCl}_{3}\right): \delta=169.2,167.0,137.2,132.9,131.7$, 130.7, 128.8, 128.3, 53.4, 52.5, 44.0.

MS (EI): $m / z(\%)=287\left(14,\left[\mathrm{M}^{+}\right]\right), 254(100), 256(84)$.

Carbothioamides 2 and Benzothiazolecarbothioamides 3; General Procedure

The corresponding nitrile $(100 \mathrm{mmol})$ prepared as described previously ${ }^{18}$ was dissolved in DMSO $(25 \mathrm{~mL})$ and $\mathrm{H}_{2} \mathrm{~S}$ was slowly bubbled through the solution until no more gas was consumed. The solution was stirred at r.t. and the reaction progress was monitored by TLC (acetone). $\mathrm{H}_{2} \mathrm{O}$ was added to precipitate the product, the solid formed was collected by filtration, and recrystallized from DMF.

\section{Pyridine-2-carbothioamide (2a)}

Yield: $11.7 \mathrm{~g}(8.5 \mathrm{mmol}, 85 \%)$; yellow crystals; $\mathrm{mp} 138-140{ }^{\circ} \mathrm{C}$ (DMF).

IR (ATR): 725, 900, 1304, 1579, $3141 \mathrm{~cm}^{-1}(\mathrm{~N}-\mathrm{H})$.

${ }^{1} \mathrm{H}$ NMR $\left(250 \mathrm{MHz}, \mathrm{DMSO}-d_{6}\right): \delta=10.13(\mathrm{~s}, 1 \mathrm{H}), 9.90(\mathrm{~s}, 1 \mathrm{H})$, $8.61-8.56(\mathrm{~m}, 1 \mathrm{H}), 8.49(\mathrm{~d}, J=8.0 \mathrm{~Hz}, 1 \mathrm{H}), 7.99-7.92(\mathrm{~m}, 1 \mathrm{H})$, $7.60-7.55(\mathrm{~m}, 1 \mathrm{H})$.

${ }^{13} \mathrm{C}$ NMR (63 MHz, DMSO- $\left.d_{6}\right): \delta=195.2,152.2,148.0,137.8$, 126.7, 124.9.

MS (EI): $m / z(\%)=138\left(100,\left[\mathrm{M}^{+}\right]\right), 79(40), 105(38)$.
Pyridine-3-carbothioamide (2b)

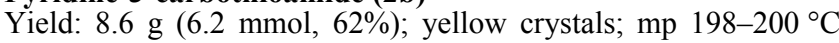
(DMF).

IR (ATR): 734, 910, 1309, 1587, 2581, 2809, 3023, $3221 \mathrm{~cm}^{-1}(\mathrm{~N}-$ $\mathrm{H})$.

${ }^{1} \mathrm{H}$ NMR $\left(250 \mathrm{MHz}, \mathrm{DMSO}-d_{6}\right): \delta=10.05(\mathrm{~s}, 1 \mathrm{H}), 9.69(\mathrm{~s}, 1 \mathrm{H})$, $8.99(\mathrm{~d}, J=2.1 \mathrm{~Hz}, 1 \mathrm{H}), 8.65(\mathrm{dd}, J=4.8,1.6 \mathrm{~Hz}, 1 \mathrm{H}), 8.35-8.04$ (m, $1 \mathrm{H}), 7.59-7.26(\mathrm{~m}, 1 \mathrm{H})$.

${ }^{13} \mathrm{C}$ NMR $\left(63 \mathrm{MHz}, \mathrm{DMSO}-d_{6}\right): \delta=198.3,152.0,148.0,135.6$, 135.2, 123.4 .

MS (EI): $m / z(\%)=138\left(100,\left[\mathrm{M}^{+}\right]\right), 105(24)$.

Pyrimidin-2-thioamide (2c)

Yield: $10.0 \mathrm{~g}$ (7.2 mmol, 72\%); yellow brown crystals; mp 192 $194{ }^{\circ} \mathrm{C}(\mathrm{DMF})$.

IR (ATR): 742, 910, 1322, 1561, 3115, $3376 \mathrm{~cm}^{-1}(\mathrm{~N}-\mathrm{H})$.

${ }^{1} \mathrm{H}$ NMR $\left(250 \mathrm{MHz}, \mathrm{DMSO}-d_{6}\right): \delta=10.27$ (s, $\left.1 \mathrm{H}\right), 9.87(\mathrm{~s}, 1 \mathrm{H})$, $8.89(\mathrm{~d}, J=4.9 \mathrm{~Hz}, 2 \mathrm{H}), 7.61(\mathrm{dd}, J=4.8 \mathrm{~Hz}, 1 \mathrm{H})$.

${ }^{13} \mathrm{C}$ NMR (63 MHz, $\left.\mathrm{CDCl}_{3}\right): \delta=196.1,161.3,157.8,122.5$.

MS (EI): $m / z(\%)=139\left(100,\left[\mathrm{M}^{+}\right]\right), 106(65), 80(52)$.

Thiophene-2-carbothioamide (2d)

Yield: $11.5 \mathrm{~g}(8.0 \mathrm{mmol}, 80 \%)$; yellow crystals; $\mathrm{mp} 94-96{ }^{\circ} \mathrm{C}$ (DMF).

IR (ATR): $680,1015,1362,1517,1620,3147,3267,3314 \mathrm{~cm}^{-1}(\mathrm{~N}-$ $\mathrm{H})$.

${ }^{1} \mathrm{H}$ NMR $\left(250 \mathrm{MHz}, \mathrm{DMSO}-d_{6}\right): \delta=9.59(\mathrm{~s}, 1 \mathrm{H}), 9.41(\mathrm{~s}, 1 \mathrm{H})$, $7.80-7.72(\mathrm{~m}, 1 \mathrm{H}), 7.68(\mathrm{dd}, J=3.8,1.0 \mathrm{~Hz}, 1 \mathrm{H}), 7.13(\mathrm{dd}, J=5.0$, $3.9 \mathrm{~Hz}, 1 \mathrm{H})$.

${ }^{13} \mathrm{C}$ NMR (63 MHz, DMSO- $\left.d_{6}\right): \delta=190.2,147.0,135.2,128.8$, 125.9 .

MS (EI): $m / z(\%)=143\left(88,\left[\mathrm{M}^{+}\right]\right), 45(100), 60(84)$.

Benzo $[d]$ thiazole-2-carbothioamide (3a)

Yield: $17.5 \mathrm{~g}$ (9 mmol, 99\%); yellow crystals; mp $210-211{ }^{\circ} \mathrm{C}$ (DMF).

IR (ATR): 758, 1011, 1293, $1580(\mathrm{C}=\mathrm{C}), 3132,3224,3396 \mathrm{~cm}^{-1}$ $(\mathrm{N}-\mathrm{H})$.

${ }^{1} \mathrm{H}$ NMR $\left(250 \mathrm{MHz}, \mathrm{DMSO}-d_{6}\right): \delta=10.37(\mathrm{~s}, 1 \mathrm{H}), 10.13(\mathrm{~s}, 1 \mathrm{H})$, $8.11(\mathrm{~m}, 2 \mathrm{H}), 7.63-7.49(\mathrm{~m}, 2 \mathrm{H})$.

${ }^{13} \mathrm{C}$ NMR $\left(63 \mathrm{MHz}, \mathrm{DMSO}-d_{6}\right): \delta=187.7,169.2,153.7,139.3$, 127.6, 127.3, 124.9, 122.9.

MS (EI): $m / z(\%)=194\left(100,\left[\mathrm{M}^{+}\right]\right), 167(40), 135$ (16).

6-Methylbenzo $[d]$ thiazole-2-carbothioamide (3b)

Yield: $17.5 \mathrm{~g}(8.4 \mathrm{mmol}, 84 \%)$; yellow crystals; mp $248-250{ }^{\circ} \mathrm{C}$ (DMF).

IR (ATR): 740, 918, 1211, $1603(\mathrm{C}=\mathrm{C}), 3135,3235,3339 \mathrm{~cm}^{-1}(\mathrm{~N}-$ $\mathrm{H})$.

${ }^{1} \mathrm{H}$ NMR $\left(250 \mathrm{MHz}, \mathrm{DMSO}-d_{6}\right): \delta=10.32(\mathrm{~s}, 1 \mathrm{H}), 10.08(\mathrm{~s}, 1 \mathrm{H})$, $8.10-7.80(\mathrm{~m}, 2 \mathrm{H}), 7.40(\mathrm{~d}, J=8.4 \mathrm{~Hz}, 1 \mathrm{H}), 3.36(\mathrm{~s}, 3 \mathrm{H})$.

${ }^{13} \mathrm{C}$ NMR $\left(63 \mathrm{MHz}, \mathrm{DMSO}-d_{6}\right): \delta=187.8,168.1,151.9,139.5$, 137.4, 129.3, 124.5, 122.3, 21.6.

MS (EI): $m / z(\%)=208\left(100,\left[\mathrm{M}^{+}\right]\right), 121(80), 181(60)$.

6-Methoxybenzo $[d]$ thiazole-2-carbothioamide (3c)

Yield: 18.2 g (8.1 mmol, 81\%); yellow crystals; mp 200-202 ${ }^{\circ} \mathrm{C}$ (DMF).

IR (ATR): 691, 1017, 1224, $1600(\mathrm{C}=\mathrm{C}), 3137,3234,3399 \mathrm{~cm}^{-1}$ $(\mathrm{N}-\mathrm{H})$. 
${ }^{1} \mathrm{H}$ NMR $\left(250 \mathrm{MHz}\right.$, DMSO- $\left.d_{6}\right): \delta=10.24(\mathrm{~s}, 1 \mathrm{H}), 10.01(\mathrm{~s}, 1 \mathrm{H})$ $7.96(\mathrm{~d}, J=9.0 \mathrm{~Hz}, 1 \mathrm{H}), 7.69(\mathrm{~d}, J=2.5 \mathrm{~Hz}, 1 \mathrm{H}), 7.17(\mathrm{dd}, J=9.0$, $2.5 \mathrm{~Hz}, 1 \mathrm{H}), 3.85$ (s, $3 \mathrm{H})$.

${ }^{13} \mathrm{C}$ NMR (63 MHz, DMSO- $\left.d_{6}\right): \delta=187.7,166.4,158.9,148.1$, 141.3, 125.7, 117.8, 104.7, 56.3.

MS (EI): $m / z(\%)=224\left(100,\left[\mathrm{M}^{+}\right]\right), 191(96), 165(78)$.

\section{6-(Benzyloxy)benzo $[d]$ thiazole-2-carbothioamide (3d)}

Yield: $25.5 \mathrm{~g}$ (8.5 mmol, 85\%); yellow powder; $\mathrm{mp} 242-244{ }^{\circ} \mathrm{C}$ (DMF).

IR (ATR): 826, 1014, 1232, $1592(\mathrm{C}=\mathrm{C}), 3148,3237,3366 \mathrm{~cm}^{-1}$ (NH).

${ }^{1} \mathrm{H}$ NMR $\left(250 \mathrm{MHz}, \mathrm{DMSO}-d_{6}\right): \delta=10.25(\mathrm{~s}, 1 \mathrm{H}), 10.02(\mathrm{~s}, 1 \mathrm{H})$, $7.98(\mathrm{~d}, J=9.0 \mathrm{~Hz}, 1 \mathrm{H}), 7.80(\mathrm{~d}, J=2.1 \mathrm{~Hz}, 1 \mathrm{H}), 7.48(\mathrm{~d}, J=6.8$ $\mathrm{Hz}, 2 \mathrm{H}), 7.38$ (dd, $J=15.4,7.6 \mathrm{~Hz}, 3 \mathrm{H}), 7.29-7.22(\mathrm{~m}, 1 \mathrm{H}), 5.19$ (s, $2 \mathrm{H})$.

${ }^{13} \mathrm{C}$ NMR (63 MHz, DMSO- $d_{6}$ ): $\delta=187.7,166.6,158.0,148.2$, $141.2,136.9,128.9,128.5,128.4,125.7,118.2,105.8,70.4$.

MS (EI): $m / z(\%)=300\left(76,\left[\mathrm{M}^{+}\right]\right), 91(100)$.

Anal. Calcd for $\mathrm{C}_{15} \mathrm{H}_{12} \mathrm{~N}_{2} \mathrm{OS}_{2}$ : C, 59.97; H, 4.03; N, 9.33; S, 21. 35. Found: C, 60.02; H, 4.02; N, 9.40; S, 21.30.

\section{6-Fluorobenzo $[d]$ thiazole-2-carbothioamide (3e)}

Yield: $16.9 \mathrm{~g}$ (8.0 mmol, $80 \%)$; yellow needles; mp $252-254{ }^{\circ} \mathrm{C}$ (DMF).

IR (ATR): 854, 1044, 1230, $1584(\mathrm{C}=\mathrm{C}), 3135,3226,3395 \mathrm{~cm}^{-1}$ $(\mathrm{N}-\mathrm{H})$.

${ }^{1} \mathrm{H}$ NMR $\left(250 \mathrm{MHz}, \mathrm{DMSO}-d_{6}\right): \delta=10.39(\mathrm{~s}, 1 \mathrm{H}), 10.13(\mathrm{~s}, 1 \mathrm{H})$, 8.13-8.02 (m, $2 \mathrm{H}), 7.49-7.41$ (m, $1 \mathrm{H})$.

${ }^{13} \mathrm{C}$ NMR (63 MHz, DMSO- $\left.d_{6}\right): \delta=187.4,169.3(\mathrm{~d}, J=3.5 \mathrm{~Hz})$, $161.0(\mathrm{~d}, J=246 \mathrm{~Hz}), 150.6(\mathrm{~d}, J=1.3 \mathrm{~Hz}), 140.7(\mathrm{~d}, J=11.8 \mathrm{~Hz})$ $126.6(\mathrm{~d}, J=9.8 \mathrm{~Hz}), 116.5(\mathrm{~d}, J=25.3 \mathrm{~Hz}), 109.1(\mathrm{~d}, J=27.2 \mathrm{~Hz})$. MS (EI): $m / z(\%)=212\left(100,\left[\mathrm{M}^{+}\right]\right), 60(50) 185(40)$.

Anal. Calcd for $\mathrm{C}_{8} \mathrm{H}_{5} \mathrm{FN}_{2} \mathrm{~S}_{2}$ : C, 45.27; H, 2.37; N, 13.20; S, 30.21 . Found: C, 45.33; H, 2.35; N, 13.21; S, 30.15.

Tricyclic Lactones 4 and 5 Based on 4-Hydroxy-1,3-thiazoles; General Procedure

Under an inert atmosphere, the corresponding thioamide $\mathbf{2}$ or $\mathbf{3}$ $(3 \mathrm{mmol})$ was dissolved in DMF $(3-5 \mathrm{~mL})$ and $\mathrm{Et}_{3} \mathrm{~N}(3 \mathrm{mmol})$ was added. The solution was stirred for $20 \mathrm{~min}$ at $30^{\circ} \mathrm{C}$ and dimethyl $\alpha$ bromohomophthalate $(1 ; 1.148 \mathrm{~g}, 4 \mathrm{mmol})$ was added. The temperature of the stirred reaction was slowly increased up to $120^{\circ} \mathrm{C}$. After $24 \mathrm{~h}$, the solid formed was collected by filtration, washed with EtOH $(10 \mathrm{~mL})$, and recrystallized from DMF.

\section{2-(Pyridin-2-yl)-5H-isochromeno[3,4-d] thiazol-5-one (4a)}

Yield: $0.6 \mathrm{~g}$ (2.1 mmol, 70\%); colorless needles; $\mathrm{mp} 270-272{ }^{\circ} \mathrm{C}$ (DMF).

IR (ATR): $805(\mathrm{C}-\mathrm{H}), 1038,1613(\mathrm{C}=\mathrm{C}), 1740(\mathrm{C}=\mathrm{O}), 2950 \mathrm{~cm}^{-1}$. ${ }^{1} \mathrm{H} \mathrm{NMR}\left(400 \mathrm{MHz}, \mathrm{CDCl}_{3}\right): \delta=8.64(\mathrm{~d}, J=4.2 \mathrm{~Hz}, 1 \mathrm{H}), 8.42(\mathrm{~d}$, $J=7.9 \mathrm{~Hz}, 1 \mathrm{H}), 8.25(\mathrm{~d}, J=7.9 \mathrm{~Hz}, 1 \mathrm{H}), 7.86-7.77(\mathrm{~m}, 2 \mathrm{H}), 7.65$ $(\mathrm{d}, J=7.7 \mathrm{~Hz}, 1 \mathrm{H}), 7.55(\mathrm{t}, J=7.6 \mathrm{~Hz}, 1 \mathrm{H}), 7.41-7.35(\mathrm{~m}, 1 \mathrm{H})$.

${ }^{13} \mathrm{C} \mathrm{NMR}\left(101 \mathrm{MHz}, \mathrm{CDCl}_{3}\right): \delta=166.4,160.8,158.0,150.6,149.5$, $137.0,135.3,132.8,131.4,128.2,125.2,123.3,120.0,119.5,110.9$ MS (EI): $m / z(\%)=280\left(48,\left[\mathrm{M}^{+}\right]\right), 120(100), 148$ (16).

Anal. Calcd for $\mathrm{C}_{15} \mathrm{H}_{8} \mathrm{~N}_{2} \mathrm{O}_{2} \mathrm{~S}$ : C, 64.27; H, 2.88; N, 9.99; S, 11.44. Found: C, 64.30; H, 2.61; N, 9.95; S, 11.16.

2-(Pyridin-3-yl)-5H-isochromeno[3,4- $d]$ thiazol-5-one (4b) Yield: $0.4 \mathrm{~g}$ (1.4 mmol, 45\%); beige powder; $\mathrm{mp} 220-222{ }^{\circ} \mathrm{C}$ (DMF).
IR (ATR): 743 (C-H), 1019, 1377, $1614(\mathrm{C}=\mathrm{C}), 1729(\mathrm{C}=\mathrm{O}), 3028$ $\mathrm{cm}^{-1}$.

${ }^{1} \mathrm{H}$ NMR $\left(250 \mathrm{MHz}, \mathrm{DMSO}-d_{6}\right): \delta=9.18(\mathrm{~d}, J=2.2 \mathrm{~Hz}, 1 \mathrm{H}), 8.73$ $(\mathrm{dd}, J=4.8,1.4 \mathrm{~Hz}, 1 \mathrm{H}), 8.39-8.33(\mathrm{~m}, 1 \mathrm{H}), 8.25(\mathrm{~d}, J=7.9 \mathrm{~Hz}$, $1 \mathrm{H}), 7.88(\mathrm{dd}, J=16.9,7.1 \mathrm{~Hz}, 2 \mathrm{H}), 7.68-7.56(\mathrm{~m}, 2 \mathrm{H})$.

${ }^{13} \mathrm{C}$ NMR $\left(63 \mathrm{MHz}, \mathrm{DMSO}-d_{6}\right): \delta=162.2,160.8,157.8,152.4$, 147.2, 136.6, 134.0, 132.1, 131.1, 129.3, 128.6, 124.9, 124.4, 119.1, 109.8 .

MS (EI): $m / z(\%)=280\left(100,\left[\mathrm{M}^{+}\right]\right), 176(40), 120(28)$.

Anal. Calcd for $\mathrm{C}_{15} \mathrm{H}_{8} \mathrm{~N}_{2} \mathrm{O}_{2} \mathrm{~S}: \mathrm{C}, 64.27 ; \mathrm{H}, 2.88 ; \mathrm{N}, 9.99 ; \mathrm{S}, 11.44$. Found: C, 64.30; H, 2.87; N, 10.05; S, 11.40 .

\section{2-(Pyrimidin-2-yl)-5H-isochromeno[3,4- $d]$ thiazol-5-one (4c)}

Yield: $0.3 \mathrm{~g}(1.1 \mathrm{mmol}, 35 \%)$; off-white fine needles; $\mathrm{mp} 308$ $310{ }^{\circ} \mathrm{C}$ (DMF).

IR (ATR): $762(\mathrm{C}-\mathrm{H})$, 1025, $1610(\mathrm{C}=\mathrm{C}), 1748(\mathrm{C}=\mathrm{O}), 3092 \mathrm{~cm}^{-1}$. ${ }^{1} \mathrm{H}$ NMR $\left(400 \mathrm{MHz}, 70{ }^{\circ} \mathrm{C}\right.$, DMSO- $\left.d_{6}\right): \delta=8.98(\mathrm{~d}, J=4.9 \mathrm{~Hz}, 2$ H), $8.30(\mathrm{~d}, J=7.9 \mathrm{~Hz}, 1 \mathrm{H}), 7.96-7.92(\mathrm{~m}, 2 \mathrm{H}), 7.73-7.65(\mathrm{~m}, 1$ $\mathrm{H}), 7.61(\mathrm{t}, J=4.9 \mathrm{~Hz}, 1 \mathrm{H})$.

${ }^{13} \mathrm{C}$ NMR (101 MHz, DMSO- $\left.d_{6}\right): \delta=206.3,163.6,160.8,158.7$, 158.1, 136.4, 132.2, 131.1, 129.7, 124.7, 122.6, 119.7, 112.9.

MS (EI): $m / z(\%)=281\left(80,\left[\mathrm{M}^{+}\right]\right), 176(100)$.

Anal. Calcd for $\mathrm{C}_{14} \mathrm{H}_{7} \mathrm{~N}_{3} \mathrm{O}_{2} \mathrm{~S}: \mathrm{C}, 59.78 ; \mathrm{H}, 2.51 ; \mathrm{N}, 14.94 ; \mathrm{S}, 11.40$. Found: C, 59.70; H, 2.50; N, 14.99; S, 11.38 .

2-(Thiophen-2-yl)-5H-isochromeno[3,4- $d \mid$ thiazol-5-one (4d) Yield: $0.6 \mathrm{~g}$ (1.95 mmol, 65\%); yellow needles; $\mathrm{mp} 210-212{ }^{\circ} \mathrm{C}$ (DMF).

IR (ATR): $694(\mathrm{C}-\mathrm{H})$, 1003, 1383, $1601(\mathrm{C}=\mathrm{C}), 1727(\mathrm{C}=\mathrm{O}), 3107$ $\mathrm{cm}^{-1}$

${ }^{1} \mathrm{H} \mathrm{NMR}\left(250 \mathrm{MHz}, \mathrm{DMSO}-d_{6}\right): \delta=8.21(\mathrm{~d}, J=7.9 \mathrm{~Hz}, 1 \mathrm{H}), 7.93-$ $7.81(\mathrm{~m}, 3 \mathrm{H}), 7.76(\mathrm{~d}, J=7.7 \mathrm{~Hz}, 1 \mathrm{H}), 7.61(\mathrm{dd}, J=11.2,4.0 \mathrm{~Hz}$, $1 \mathrm{H}), 7.23$ (dd, $J=4.9,3.9 \mathrm{~Hz}, 1 \mathrm{H})$.

${ }^{13} \mathrm{C}$ NMR $\left(63 \mathrm{MHz}\right.$, DMSO- $\left.d_{6}\right): \delta=160.9,159.1,157.1,136.5$, 135.9, 132.3, 131.6, 131.0, 129.4, 129.2, 128.9, 124.0, 118.9, 108.0.

MS (EI): $m / z(\%)=285\left(100,\left[\mathrm{M}^{+}\right]\right), 176(28), 120(36)$.

Anal. Calcd for $\mathrm{C}_{14} \mathrm{H}_{7} \mathrm{NO}_{2} \mathrm{~S}_{2}$ : C, 58.93; H, 2.47; N, 4.91; S, 22.47. Found: C, 58.93; H, 2.30; N, 4.99; S, 22.43.

\section{Crystal Data for $\mathbf{4} \mathbf{d}^{19}$}

$\mathrm{C}_{14} \mathrm{H}_{7} \mathrm{NO}_{2} \mathrm{~S}_{2}, \quad \mathrm{Mr}=285.33 \mathrm{~g} \mathrm{~mol}^{-1}$, colorless prism, size $0.07 \times 0.03 \times 0.03 \mathrm{~mm}^{3}$, monoclinic, space group $\mathrm{P} 2_{1}$, $a=3.8212(2), b=14.0344(9), c=11.2879(8) \AA, \beta=95.856(3)^{\circ}$, $V=602.19(7) \AA^{3}, T=-140{ }^{\circ} \mathrm{C}, Z=2, \rho_{\text {calcd }}=1.574 \mathrm{gcm}^{-3}, \mu$ $\left(\mathrm{MoK}_{\alpha}\right)=4.36 \mathrm{~cm}^{-1}, F(000)=292,3482$ reflections in $h(-4 / 4)$, $k(-18 / 15), l(-14 / 10)$, measured in the range $3.63^{\circ} \leq \Theta \leq 27.44^{\circ}$, completeness $\Theta_{\max }=98.9 \%, 2382$ independent reflections, $R_{\text {int }}=0.0243,2283$ reflections with $F_{\mathrm{o}}>4 \rho\left(\mathrm{F}_{\mathrm{o}}\right), 191$ parameters, 1 restraints, $\quad R 1_{\text {obs }}=0.0352, \quad w R 2_{\text {obs }}=0.0777, \quad R 1_{\text {all }}=0.0386$, $w R 2_{\text {all }}=0.0806, \mathrm{GOOF}=1.143$, Flack-parameter $0.10(9)$, largest difference peak and hole: $0.244 /-0.194 \mathrm{e} \AA^{-3}$.

Selected bond lengths ( $\AA$ ): C4-C5 1.443 (3); C6-C7 1.367 (4); C9C14 1.411 (3); C8-O2 1.204 (4); C5-N1 1.314 (4); C5-S2 1.745 (3); C4-S1 1.718 (4); torsion angle [ $\left.{ }^{\circ}\right] \mathrm{S} 1-\mathrm{C} 4-\mathrm{C} 5-\mathrm{S} 2176.20$ (2).

\section{2-(Benzo $[d]$ thiazol-2-yl)-5H-isochromeno $[3,4-d]$ thiazol-5-one}

(5a)

Yield: $0.5 \mathrm{~g}$ (1.5 mmol, 49\%); yellow needles; mp 190-192 ${ }^{\circ} \mathrm{C}$ (DMF).

IR (ATR): 760 (C-H), 917, 1480, $1600(\mathrm{C}=\mathrm{C}), 1737(\mathrm{C}=\mathrm{O}) \mathrm{cm}^{-1}$.

${ }^{1} \mathrm{H}$ NMR $\left(400 \mathrm{MHz}, 70{ }^{\circ} \mathrm{C}\right.$, DMSO- $\left.d_{6}\right): \delta=8.32(\mathrm{~d}, J=8.4 \mathrm{~Hz}, 1$ $\mathrm{H}), 8.23(\mathrm{~d}, J=7.4 \mathrm{~Hz}, 1 \mathrm{H}), 8.16(\mathrm{~d}, J=8.3 \mathrm{~Hz}, 1 \mathrm{H}), 7.99(\mathrm{~s}, 2 \mathrm{H})$, $7.73(\mathrm{~s}, 1 \mathrm{H}), 7.65(\mathrm{~s}, 1 \mathrm{H}), 7.59(\mathrm{~s}, 1 \mathrm{H})$. 
MS (EI): $m / z(\%)=336\left(100,\left[\mathrm{M}^{+}\right]\right), 176(44), 120(32)$.

Anal. Calcd for $\mathrm{C}_{17} \mathrm{H}_{8} \mathrm{~N}_{2} \mathrm{O}_{2} \mathrm{~S}_{2}: \mathrm{C}, 60.70 ; \mathrm{H}, 2.40 ; \mathrm{N}, 8.33 ; \mathrm{S}, 19.06$. Found: C, 60.65; H, 2.26; N, 8.56; S, 19.14 .

\section{Crystal Data for $\mathbf{5 a}^{19}$}

$\mathrm{C}_{17} \mathrm{H}_{8} \mathrm{~N}_{2} \mathrm{O}_{2} \mathrm{~S}_{2}, \quad \mathrm{Mr}=336.37$ gmol $^{-1}$, yellow prism, size $0.06 \times 0.06 \times 0.05 \mathrm{~mm}^{3}$, orthorhombic, space group $\mathrm{P}$ bca, $a=$ 7.0319(2), $b=14.3660(3), c=27.3922(9) \AA, V=2767.17(13) \AA^{3}$, $T=-140{ }^{\circ} \mathrm{C}, Z=8, \rho_{\text {calcd }}=1.615 \mathrm{gcm}^{-3}, \mu\left(\mathrm{MoK}_{\alpha}\right)=3.96 \mathrm{~cm}^{-1}$, $F(000)=1376,16319$ reflections in $h(-9 / 8), k(-18 / 18), l(-35 / 33)$, measured in the range $2.84^{\circ} \leq \Theta \leq 27.50^{\circ}$, completeness $\Theta_{\max }=99.7 \%, 3169$ independent reflections, $R_{\text {int }}=0.0486,2795 \mathrm{re}-$ flections with $F_{\mathrm{o}}>4 \rho\left(F_{\mathrm{o}}\right), 240$ parameters, 0 restraints, $R 1_{\text {obs }}=0.0389, w R 2_{\text {obs }}=0.0851, R 1_{\text {all }}=0.0472, w R 2_{\text {all }}=0.0892$, $\mathrm{GOOF}=1.096$, largest difference peak and hole: $0.385 /-0.269 \mathrm{e} \AA^{-3}$.

Selected bond lengths $(\AA)$ : C7-C8 1.453 (3); C9-C17 1.363 (2); C11-C16 1.410 (3); C10-O2 1.201 (2); C7-S1 1.742 (2); C8-S2 1.728 (2); C7-N1 1.302 (2); C8-N2 1.314 (2); C1-C6 1.411 (3); torsion angle $\left[{ }^{\circ}\right] \mathrm{S} 1-\mathrm{C} 7-\mathrm{C} 8-\mathrm{S} 2174.42(1)$.

2-(6-Methylbenzo $[d]$ thiazol-2-yl)-5H-isochromeno $[3,4-d]$ thiazol-5-one (5b)

Yield: $0.5 \mathrm{~g}$ (1.44 mmol, 48\%); yellow needles; $\mathrm{mp}>340{ }^{\circ} \mathrm{C}$ (DMF).

IR (ATR): 760 (C-H), 807, 917, 1600 (C=C), 1733 (C=O), 3061 $\mathrm{cm}^{-1}$.

${ }^{1} \mathrm{H}$ NMR $\left(400 \mathrm{MHz}, 70{ }^{\circ} \mathrm{C}\right.$, DMSO- $\left.d_{6}\right): \delta=8.32(\mathrm{~d}, J=7.2 \mathrm{~Hz}, 1$ H), 8.02 (s, $2 \mathrm{H}), 7.97$ (s, $2 \mathrm{H}), 7.73(\mathrm{~s}, 1 \mathrm{H}), 7.48$ (s, $1 \mathrm{H}), 2.33$ (s, $3 \mathrm{H})$.

MS (EI): $m / z(\%)=350\left(46,\left[\mathrm{M}^{+}\right]\right), 120(100), 176(56)$.

Anal. Calcd for $\mathrm{C}_{18} \mathrm{H}_{10} \mathrm{~N}_{2} \mathrm{O}_{2} \mathrm{~S}_{2}: \mathrm{C}, 61.70 ; \mathrm{H}, 2.88 ; \mathrm{N}, 7.99 ; \mathrm{S}, 18.30$. Found: C, 61.68; H, 2.86; N, 7.95; S, 18.35 .

2-(6-Methoxybenzo $[d]$ thiazol-2-yl)-5H-isochromeno[3,4- $d]$ thiazol-5-one (5c)

Yield: $0.6 \mathrm{~g}$ (1.5 mmol, 51\%); yellow powder; mp 200-202 ${ }^{\circ} \mathrm{C}$ (DMF).

IR (ATR): $751(\mathrm{C}-\mathrm{H}), 1017,1050,1600(\mathrm{C}=\mathrm{C}), 1723 \mathrm{~cm}^{-1}(\mathrm{C}=\mathrm{O})$.

${ }^{1} \mathrm{H}$ NMR $\left(400 \mathrm{MHz}, 70{ }^{\circ} \mathrm{C}\right.$, DMSO- $\left.d_{6}\right): \delta=8.31(\mathrm{~s}, 1 \mathrm{H}), 8.08-8.01$ (m, $1 \mathrm{H}), 7.97(\mathrm{~s}, 2 \mathrm{H}), 7.79(\mathrm{~s}, 1 \mathrm{H}), 7.76-7.67(\mathrm{~m}, 1 \mathrm{H}), 7.28-7.22$ $(\mathrm{m}, 1 \mathrm{H}), 3.92(\mathrm{~s}, 3 \mathrm{H})$.

MS (EI): $m / z(\%)=366\left(86,\left[\mathrm{M}^{+}\right]\right), 120$ (100), 148 (44).

Anal. Calcd for $\mathrm{C}_{18} \mathrm{H}_{10} \mathrm{~N}_{2} \mathrm{O}_{3} \mathrm{~S}_{2}: \mathrm{C}, 59.00 ; \mathrm{H}, 2.75 ; \mathrm{N}, 7.65 ; \mathrm{S}, 17.50$. Found: C, 59.05; H, 2.70; N, 7.69; S, 17.52.

2-(6-Benzyloxybenzo $[d]$ thiazol-2-yl)-5H-isochromeno[3,4$d$ thiazol-5-one (5d)

Yield: $0.6 \mathrm{~g}$ (1.4 mmol, 46\%); yellow powder; mp $272-274{ }^{\circ} \mathrm{C}$ (DMF).

IR (ATR): 759 (C-H), 1217, 1368, $1598(\mathrm{C}=\mathrm{C}), 1740(\mathrm{C}=\mathrm{O}), 3030$ $\mathrm{cm}^{-1}$.

${ }^{1} \mathrm{H}$ NMR $\left(400 \mathrm{MHz}, 70{ }^{\circ} \mathrm{C}, \mathrm{DMSO}-d_{6}\right): \delta=8.30(\mathrm{~s}, 1 \mathrm{H}), 8.06(\mathrm{~d}$, $J=8.4 \mathrm{~Hz}, 1 \mathrm{H}), 7.97(\mathrm{~s}, 2 \mathrm{H}), 7.88(\mathrm{~s}, 1 \mathrm{H}), 7.71(\mathrm{~s}, 1 \mathrm{H}), 7.50(\mathrm{~s}$, $2 \mathrm{H}), 7.42(\mathrm{~s}, 2 \mathrm{H}), 7.33(\mathrm{~s}, 2 \mathrm{H}), 5.26(\mathrm{~s}, 2 \mathrm{H})$.

MS (EI): $m / z(\%)=442\left(24,\left[\mathrm{M}^{+}\right]\right), 91(100), 120(88)$.

Anal. Calcd for $\mathrm{C}_{24} \mathrm{H}_{14} \mathrm{~N}_{2} \mathrm{O}_{3} \mathrm{~S}_{2}: \mathrm{C}, 65.14 ; \mathrm{H}, 3.19 ; \mathrm{N}, 6.33 ; \mathrm{S}, 14.49$. Found: C, 65.16; H, 3.17; N, 6.38; S, 14.45 .

\section{2-(6-Fluorobenzo $[d]$ thiazol-2-yl)-5H-isochromeno[3,4- $d]$ thia-} zol-5-one (5e)

Yield: $0.8 \mathrm{~g}$ (2.3 mmol, 78\%); yellow powder; mp 340-342 ${ }^{\circ} \mathrm{C}$ (DMF).
IR (ATR): $757(\mathrm{C}-\mathrm{H}), 837,1604(\mathrm{C}=\mathrm{C}), 1741(\mathrm{C}=\mathrm{O}), 3064 \mathrm{~cm}^{-1}$. ${ }^{1} \mathrm{H}$ NMR $\left(400 \mathrm{MHz}, 70{ }^{\circ} \mathrm{C}\right.$, DMSO- $\left.d_{6}\right): \delta=8.31(\mathrm{~d}, J=7.8 \mathrm{~Hz}, 1$ $\mathrm{H}), 8.18(\mathrm{dd}, J=9.0,5.1 \mathrm{~Hz}, 1 \mathrm{H}), 8.11(\mathrm{dd}, J=8.7,2.6 \mathrm{~Hz}, 1 \mathrm{H})$, $7.98(\mathrm{~d}, J=3.0 \mathrm{~Hz}, 2 \mathrm{H}), 7.74-7.70(\mathrm{~m}, 1 \mathrm{H}), 7.49$ (dd, $J=10.3,7.6$ $\mathrm{Hz}, 1 \mathrm{H})$.

MS (EI): $m / z(\%)=354\left(94,\left[\mathrm{M}^{+}\right]\right), 120$ (100), 148 (70).

Anal. Calcd for $\mathrm{C}_{17} \mathrm{H}_{7} \mathrm{FN}_{2} \mathrm{O}_{2} \mathrm{~S}_{2}$ : C, 57.62; H, 1.99; N, 7.90; S, 18.10 . Found: C, 57.60; H, 1.95; N, 7.95; S, 18.15.

\section{Acknowledgment}

We are very grateful for the financial support by DAAD (grant for Lorena Calderón Ortiz). Our special thanks go to Prof. Uwe Ritter for the provision of the equipments and assistance in solid-state fluorescence measurements.

Supporting Information for this article is available online at http://www.thieme-connect.com/ejournals/toc/synthesis.

\section{References}

(1) Stippich, K.; Weiß, D.; Güther, A.; Görls, H.; Beckert, R. J. Sulfur Chem. 2009, 30, 109.

(2) Täuscher, E.; Weiß, D.; Beckert, R.; Fabian, R.; Assumpsao, A.; Görls, H. Tetrahedron Lett. 2011, 52, 2292.

(3) Täuscher, E.; Weiß, D.; Beckert, R.; Görls, H. Synthesis 2010, 1603.

(4) Menzel, R.; Täuscher, E.; Weiß, D.; Beckert, R.; Görls, H. Z. Anorg. Allg. Chem. 2010, 636, 1380.

(5) Menzel, R.; Breul, A.; Pietsch, C.; Schäfer, J.; Friebe, C.; Täuscher, E.; Weiß, D.; Dietzek, B.; Popp, J.; Beckert, R.; Schubert, U. S. Macromol. Chem. Phys. 2011, 212, 840.

(6) Menzel, R.; Kupfer, S.; Mede, R.; Weiß, D.; Görls, H.; González, L.; Beckert, R. Eur. J. Org. Chem. 2012, 27, 5231.

(7) Täuscher, E.; Weiß, D.; Beckert, R.; Görls, H. Synthesis 2011, 2334.

(8) Calderón-Ortiz, L. K.; Täuscher, E.; Leite-Bastos, E.; Görls, H.; Weiß, D.; Beckert, R. Eur. J. Org. Chem. 2012, 2535.

(9) Dong, B.; Wang, M.; Xu, C.; Feng, Q.; Wang, Y. Cryst. Growth Des. 2012, 12, 5986.

(10) (a) Park, S. Y.; Ebihara, M.; Kubota, Y.; Funabiki, K.; Masaki, K.; Matsui, M. Dyes Pigments 2009, 82, 258. (b) Matsui, M.; Fukuschima, M.; Kubota, Y.; Funabiki, K.; Schiro, M. Tetrahedron 2012, 68, 1932. (c) Gupta, R.; Thomas, R.; Kulkarni, G. J. Mater. Chem. 1012, 22, 19139.

(11) Delalande, Z. Justus Liebigs Ann. Chem. 1843, 45, 332.

(12) (a) Linnell, R. J. Org. Chem. 1960, 25, 290. (b) Bordwell, F. G. Acc. Chem. Res. 1988, 21, 456.

(13) Öğretir, C.; Görgün, K.; Özkütük, M.; Sakarya, H. C. ARKIVOC 2009, (vii), 197.

(14) COLLECT, Data Collection Software; Nonius B.V.: Delft, The Netherlands, 1998.

(15) Otwinowski, Z.; Minor, W. Methods Enzymol. 1997, 276, 307.

(16) Sheldrick, G. M. Acta Crystallogr., Sect. A 2008, 46, 112.

(17) Billamboz, M.; Bailly, F.; Cotelle, P. J. Heterocycl. Chem. 2009, 46, 392.

(18) (a) Würfel, H.; Weiß, D.; Beckert, R.; Güther, A. J. Sulfur Chem. 2012, 33, 9. (b) Würfel, H. Ph.D. Thesis; Friedrich Schiller Universität: Germany, 2012.

(19) Crystallographic data (excluding structure factors) have been deposited with the Cambridge Crystallographic Data 
Centre as supplementary publication CCDC-936840 for $\mathbf{4 d}$ and CCDC-936841 for 5a. These data can be obtained free of charge from the Cambridge Crystallographic Data Centre via www.ccdc.cam.ac.uk/data_request/cif or by writing to the Cambridge Crystallographic Data Centre, 12, Union Road, Cambridge CB2 1EZ, UK; fax: +44(1223)336033;

E-mail: deposit@ccdc.cam.ac.uk 